\title{
Histamine inhibits activation of human neutrophils and HL-60 leukemic cells via $\mathrm{H}_{2}$-receptors
}

\author{
Rahel Burde $^{1}$, Roland Seifert ${ }^{1}$, Armin Buschauer ${ }^{2}$, and Günter Schultz ${ }^{1}$ \\ ${ }^{1}$ Institut für Pharmakologie, Freie Universität Berlin, Thielallee 69/73, D-1000 Berlin 33 \\ 2 Institut für Pharmazie, Freie Universität Berlin, Königin-Luise-Strasse 2-4, D-1000 Berlin 33
}

\begin{abstract}
Summary. The effects of prostaglandin $\mathrm{E}_{1}\left(\mathrm{PGE}_{1}\right)$ and histamine on activation of superoxide $\left(\mathrm{O}_{2}^{-}\right)$formation, exocytosis of $\beta$-glucuronidase and aggregation in human neutrophils and HL-60 leukemic cells were studied. $\mathrm{PGE}_{1}$, histamine and impromidine, a potent $\mathrm{H}_{2}$-agonist, inhibited $\mathrm{O}_{2}^{-}$ formation in neutrophils induced by the chemotactic peptide, N-formyl-L-methionyl-L-leucyl-L-phenylalanine (fMet-Leu-Phe) with $\mathrm{IC}_{50}$ values of $0.5 \mu \mathrm{M}, 8 \mu \mathrm{M}$ and $2 \mu \mathrm{M}$, respectively. The full $\mathrm{H}_{1}$-agonist and weak partial $\mathrm{H}_{2}-$ agonist, betahistine, was much less potent and effective than histamine. Dibutyryl cyclic AMP and forskolin mimicked the effects of histamine and $\mathrm{PGE}_{1}$ on $\mathrm{O}_{2}^{-}$formation. The $\mathrm{H}_{2}$-antagonist, famotidine, competitively reversed histamine-induced inhibition of $\mathrm{O}_{2}^{-}$formation with a $\mathrm{pA}_{2}$ value of 7.5. Histamine inhibited $\mathrm{O}_{2}^{-}$formation when added prior to or after fMet-Leu-Phe. fMet-Leu-Phe-induced aggregation and release of $\beta$-glucuronidase in neutrophils were less sensitive to inhibition by $\mathrm{PGE}_{1}$, histamine, dibutyryl cyclic AMP and forskolin than $\mathrm{O}_{2}^{-}$formation. The inhibitor of cyclic AMP-specific phosphodiesterase, rac-4-(3-butoxy4-methoxybenzyl)-2-imidazolidinone (Ro 20-1724), additively enhanced the inhibitory effects of histamine and $\mathrm{PGE}_{1}$ on the above cell functions. In HL-60 cells differentiated by dimethyl sulfoxide or dibutyryl cyclic AMP, histamine, impromidine and $\mathrm{PGE}_{1}$ but not betahistine inhibited fMet-Leu-Phe-induced $\mathrm{O}_{2}^{-}$formation as well. Our data suggest that histamine inhibits activation of neutrophils and HL-60 cells via $\mathrm{H}_{2}$-receptors through activation of adenylyl cyclase and increased formation of cyclic AMP. As stimulated basophils and mast cells release high quantities of histamine, this intercellular signal molecule may play an inhibitory role in the activation of cytotoxic functions of myeloid cells.
\end{abstract}

Key words: Superoxide formation - Exocytosis - Aggregation - Adenylyl cyclase - Histamine

\section{Introduction}

Human neutrophils play an important role in the pathogenesis of inflammatory processes and are activated by a variety of intercellular signal molecules such as formyl peptides, platelet activating factor (PAF) and ATP (Malech and Gallin 1987; Sandborg and Smolen 1988; Kuhns et al. 1988; Seifert et al. $1989 \mathrm{c})$. Upon exposure to the formyl peptide, N-

Send offprint requests to $\mathrm{R}$. Seifert at the above address
formyl-L-methionyl-L-leucyl-L-phenylalanine (fMet-LeuPhe), neutrophils generate superoxide anions $\left(\mathrm{O}_{2}^{-}\right)$, the formation of which is catalyzed by NADPH oxidase (Rossi 1986; Seifert et al. 1989a-c). PAF and ATP potentiate fMet-Leu-Phe-induced $\mathrm{O}_{2}^{-}$formation (Dewald and Baggiolini 1985; Kuhns et al. 1988; Ward et al. 1988; Seifert et al. $1989 \mathrm{c})$. In addition, fMet-Leu-Phe induces aggregation and exocytosis of $\beta$-glucuronidase (Korchak et al. 1984; Seifert et al. $1989 \mathrm{c}$ ). Receptors for formyl peptides, PAF and ATP couple to guanine nucleotide-binding proteins (G-proteins), stimulating phospholipase $\mathrm{C}$ with consequent activation of protein kinase C and calcium mobilization (Rossi 1986; Dubyak et al. 1988; Kuhns et al. 1988; Seifert et al. 1989a, b). Activation of aggregation and exocytosis may involve calcium-dependent processes and activation of protein kinase C (Sandborg and Smolen 1988). $\mathrm{O}_{2}^{-}$formation is activated by multiple mechanisms involving protein kinase $\mathrm{C}$ and direct activation by G-proteins (Rossi 1986; Seifert et al. 1986; Sandborg and Smolen 1988).

Agents which increase the intracellular concentration of cyclic AMP inhibit $\mathrm{O}_{2}^{-}$formation and exocytosis. Among these agents is the intercellular signal molecule, prostaglandin $\mathrm{E}_{1}\left(\mathrm{PGE}_{1}\right)$, which activates adenylyl cyclase in human neutrophils (Stolc 1977; Lad et al. 1985; Gryglewski et al. 1987). In addition, the unspecific inhibitor of phosphodiesterases (PDE), 3-isobutyl-1-methylxanthine (IBMX), and the specific inhibitor of cyclic AMP-specific PDE, rac-4(3-butoxy-4-methoxybenzyl)-2-imidazolidone (Ro 20-1724) inhibit $\mathrm{O}_{2}^{-}$formation (Lad et al. 1985; Weishaar 1987).

Histamine is released from stimulated basophils and mast cells and plays an important role in the pathogenesis of inflammatory processes as well (Siraganian 1983; Owen 1987). Histamine receptors are classified into $\mathrm{H}_{1}-\mathrm{H}_{2}$ - and $\mathrm{H}_{3}$-receptors according to the potency order of histaminergic agonists and antagonists (Ash and Schild 1966; Black et al. 1972; Durant et al. 1978; Arrang et al. 1983, 1987; Schwartz et al. 1986; Buschauer et al. 1989). Occupancy of $\mathrm{H}_{1}-$ and $\mathrm{H}_{2}$-receptors by agonists leads to the activation of phospholipase $\mathrm{C}$ and adenylyl cyclase, respectively (Schwartz et al. 1986; Buschauer et al. 1989).

There is a controversy concerning the role of histamine in the regulation of neutrophil functions. On one hand, particle-bound histamine induces $\mathrm{O}_{2}^{-}$formation in alveolar macrophages via $\mathrm{H}_{1}$-receptors (Diaz et al. 1979). In addition, histamine has been reported to induce the formation of thromboxanes in human neutrophils and to stimulate chemokinesis (Seligmann et al. 1983; Puustinen and Uotila 1984). On the other hand, histamine has been reported to inhibit chemotaxis and fMet-Leu-Phe-induced $\mathrm{O}_{2}^{-}$forma- 
tion in human neutrophils (Seligmann et al. 1983). With respect to the release of $\beta$-glucuronidase, histamine has been reported to inhibit exocytosis or to be without effect (Plaut and Lichtenstein 1982). In addition, histamine activates adenylyl cyclase in membranes of neutrophils and induces accumulation of cyclic AMP in these cells and in HL-60 leukemic cells via $\mathrm{H}_{2}$-receptors (Stolc 1977; Gespach and Abita 1982; Gespach et al. 1982).

These controversial data prompted us to study in detail the role of histamine in the regulation of various neutrophil functions, i.e. $\mathrm{O}_{2}^{-}$formation, exocytosis and aggregation in comparison to $\mathrm{PGE}_{1}$. We here report that histamine inhibits activation of neutrophils and HL-60 cells induced by various intercellular signal molecules. Our results suggest that the effects of histamine involve $\mathrm{H}_{2}$-receptors and an increase in the intracellular concentration of cyclic AMP.

\section{Materials and methods}

Materials. Impromidine was synthesized according to the method described by Durant et al. (1985). PAF (1-0-hexadecyl-2-acetyl-sn-glyceryl-3-phosphorylcholine) was a gift from Dr. S. Nigam (Abteilung für Gynäkologische Endokrinologie, Universitätsklinikum Steglitz, Freie Universität Berlin, FRG) and Ro 20-1724 was provided by Drs. U. Fischer and H. Gutmann (Hoffmann La-Roche, Basel, Switzerland). Diphenyldramine, fMet-Leu-Phe, N-tbutoxycarbonyl-L-phenylalanyl-L-leucyl-L-phenylalanyl-Lleucyl-L-phenylalanine (Boc-PLPLP), cytochalasin B (CB), $\mathrm{PGE}_{1}$, superoxide dismutase, ferricytochrome C, IBMX, famotidine, forskolin and $\mathrm{p}$-nitrophenyl- $\beta$-D-glucuronide were from Sigma Chemie (Taufkirchen, FRG). $\mathrm{N}^{\alpha}$-methyl2-pyridylethylamine (betahistine) and cimetidine were from Aldrich Chemie (Steinheim, FRG). Dibutyryl cyclic AMP (dbcAMP) was from Pharma Waldhof (Düsseldorf, FRG). All cell culture media were from Biochrom (Berlin, FRG). Stock solutions of fMet-Leu-Phe $(10 \mathrm{mM})$, Boc-PLPLP $(50 \mathrm{mM})$, cimetidine $(100 \mathrm{mM})$ and $\mathrm{CB}(5 \mathrm{mg} / \mathrm{ml})$ were prepared in dimethyl sulfoxide $\left(\mathrm{Me}_{2} \mathrm{SO}\right)$ and were stored at $20^{\circ} \mathrm{C}$. Forskolin $(30 \mathrm{mM})$, Ro 20-1724 (10 mM), PAF $(10 \mathrm{mM})$ and $\mathrm{PGE}_{1}(2.5 \mathrm{mM})$ were dissolved in absolute ethanol and stored at $-20^{\circ} \mathrm{C}$. Fresh stock solutions of histamine, betahistine and diphenhydramine $(100 \mathrm{mM}$ each in distilled water), famotidine and impromidine $(10 \mathrm{mM}$ in distilled water) were prepared daily. Sources of other materials have been described elsewhere (Seifert et al. 1986, 1989a - c; Seifert and Schultz 1987; Seifert and Schächtele 1988).

Isolation of neutrophils. Human neutrophils were isolated according to the procedure described by Markert et al. (1984) and Seifert et al. (1989 b). Briefly, blood was obtained from healthy volunteers of either sex who had taken no drugs for at least three weeks. Neutrophils were isolated by dextran sedimentation and centrifugation through FicollHypaque. Cell preparations consisted of more than $98 \%$ viable neutrophils as judged by trypan blue dye exclusion and Pappenheim-stained smears.

Cell culture. HL-60 cells were grown in suspension culture in RPMI-1640 medium supplemented with $10 \%$ (by volume) horse serum, $1 \%$ (by volume) non-essential amino acids, $2 \mathrm{mM}$ L-glutamine, $50 \mathrm{U} / \mathrm{ml}$ penicillin and $50 \mu \mathrm{g} / \mathrm{ml}$ streptomycin in a humidified atmosphere with $7 \% \mathrm{CO}_{2}$ at $37^{\circ} \mathrm{C}$.
To induce differentiation, HL-60 cells were seeded at a density of $10^{6}$ cells $/ \mathrm{ml}$ and were cultured for $48 \mathrm{~h}$ with $0.2 \mathrm{mM}$ dbcAMP or for $120 \mathrm{~h}$ with $160 \mathrm{mM} \mathrm{Me}{ }_{2} \mathrm{SO}$ (Chaplinski and Niedel 1982; Seifert and Schultz 1987; Seifert and Schächtele 1988). Pappenheim-stained smears showed that $\mathrm{Me}_{2} \mathrm{SO}$ - and dbcAMP-differentiated HL-60 cells consisted of more than $98 \%$ myelocytes or cells beyond this stage.

Assay for superoxide formation. $\mathrm{O}_{2}^{-}$formation was monitored by continuous measurement of ferricytochrome $\mathrm{C}$ reduction inhibitable by superoxide dismutase, using an Uvikon 810 dual-beam spectrophotometer (Kontron, Eching, FRG) (Markert et al. 1984; Seifert et al. 1989b). Reaction mixtures $(0.5 \mathrm{ml})$ contained $0.5-1.0 \times 10^{6}$ neutrophils or $2.5 \times 10^{6}$ HL-60 cells, $100 \mu \mathrm{M}$ ferricytochrome $\mathrm{C}$ and a buffer consisting of $(\mathrm{mM}) 138 \mathrm{NaCl}, 6 \mathrm{KCl}, 1 \mathrm{MgCl}_{2}$, $1 \mathrm{CaCl}_{2}, \quad 1 \mathrm{Na}_{2} \mathrm{HPO}_{4}, \quad 5 \mathrm{NaHCO}_{3}, \quad 5.5$ glucose and 20 Hepes/ $\mathrm{NaOH}, \mathrm{pH} 7.4$. Reaction mixtures were preincubated for $5 \mathrm{~min}$ at $37^{\circ} \mathrm{C}$ in the presence of the agents indicated. The absolute amounts of $\mathrm{O}_{2}^{-}$generated were calculated.

Assay for release of $\beta$-glucuronidase. Neutrophils $\left(2.5 \times 10^{6}\right.$ cells) were suspended in $500 \mu \mathrm{l}$ of the buffer described above and were incubated for $5 \mathrm{~min}$ at $37^{\circ} \mathrm{C}$ in the presence of $\mathrm{CB}$ $(5 \mu \mathrm{g} / \mathrm{ml})$ and in the absence or presence of various agents. Reactions were initiated by the addition of fMet-Leu-Phe. After $10 \mathrm{~min}$, reactions were terminated by placing the tubes onto melting ice. Reaction mixtures were centrifuged for $10 \mathrm{~min}$ at $250 \times \mathrm{g}$ at $4^{\circ} \mathrm{C}$. The determinations of $\beta$-glucuronidase and lactate dehydrogenase activities of the supernatant fluids of the reaction mixtures were performed as described (Absolom 1986; Seifert et al. 1989c). The release of lactate dehydrogenase and $\beta$-glucuronidase (in \% of total cellular content) was calculated.

Aggregation of neutrophils. Aggregation was measured by turbidometry (Korchak et al. 1984; Seifert et al. 1989c). Neutrophils $\left(5 \times 10^{6}\right.$ cells $)$ were suspended in $900 \mu$ of the buffer described above. Cells were incubated for $3 \mathrm{~min}$ in the presence or absence of various agents prior to the addition of fMet-Leu-Phe. Aggregation experiments were carried out under constant stirring of cells at $10^{3} \mathrm{rpm}$, using an Uvikon 810 dual-beam spectrophotometer. The maximum extent of aggregation was calculated.

\section{Results}

Superimposed kinetic registrations of $\mathrm{O}_{2}^{-}$formation in human neutrophils are shown in Fig. 1. fMet-Leu-Phe at a maximally effective concentration $(1 \mu \mathrm{M})$ reversibly activated $\mathrm{O}_{2}^{-}$, formation which ceased after 6 min (trace 5 ). In contrast, histamine at a concentration of $1 \mathrm{mM}$ did not activate $\mathrm{O}_{2}^{-}$formation (trace 1). When added 5 min prior to or simultaneously with fMet-Leu-Phe, histamine inhibited $\mathrm{O}_{2}^{-}$formation (trace 2 ). In addition, histamine rapidly terminated $\mathrm{O}_{2}^{-}$formation when added after fMet-Leu-Phe (traces 3 and 4). Similar results as with histamine were obtained with $\mathrm{PGE}_{1}$ (data not shown). A ten-fold excess of the competitive antagonist of fMet-Leu-Phe, Boc-PLPLP (Jesaitis et al. 1986), completely prevented activation of $\mathrm{O}_{2}^{-}$formation by the chemotactic peptide. In addition, BocPLPLP rapidly terminated fMet-Leu-Phe-induced $\mathrm{O}_{2}^{-}$formation (data not shown). 


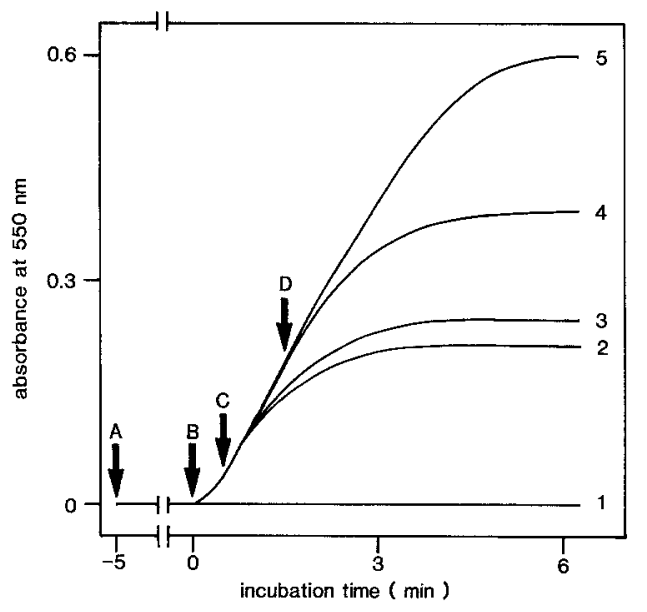

Fig. 1. Kinetics of $\mathrm{O}_{2}^{-}$formation in human neutrophils. The effect of histamine on the kinetics of fMet-Leu-Phe-induced $\mathrm{O}_{2}^{-}$formation was studied. Superimposed original registrations are shown. $A, B$, $C$ and $D$ indicate the addition of various agents at different times. Trace 1: $B$, histamine $(1 \mathrm{mM})$. Trace $2: B$, fMet-Leu-Phe $(1 \mu \mathrm{M})$; A or B, histamine $(1 \mathrm{mM})$. Trace $3: B$, fMet-Leu-Phe $(1 \mu \mathrm{M}) ; \mathrm{C}$, histamine $(1 \mathrm{mM})$. Trace $4: B$, fMet-Leu-Phe $(1 \mu \mathrm{M}) ; D$, histamine $(1 \mathrm{mM})$. Trace 5: $B$, fMet-Leu-Phe $(1 \mu \mathrm{M})$. Similar results were obtained in three experiments performed with neutrophils of different donors

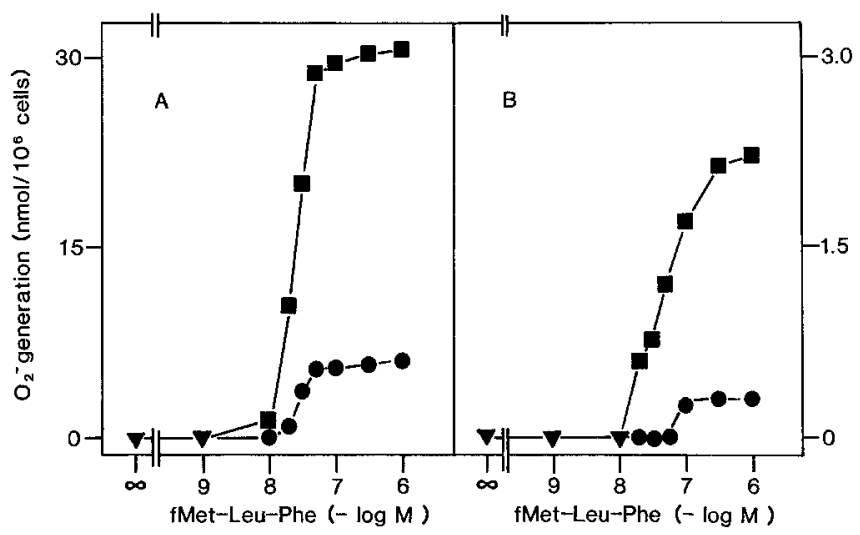

Fig. 2A, B. Effect of histamine on concentration-response curves for fMet-Leu-Phe-induced $\mathrm{O}_{2}^{-}$formation in human neutrophils. The effect of histamine $(1 \mathrm{mM})$ on fMet-Leu-Phe-induced $\mathrm{O}_{2}^{-}$formation was studied in the presence of CB $(1 \mu \mathrm{g} / \mathrm{ml})$ (Panel A) or in the absence of CB (Panel B). CB and histamine or solvent (control) were added to reaction mixtures $5 \mathrm{~min}$ prior to fMet-Leu-Phe. fMetLeu-Phe $\pm \mathrm{CB}(\mathbf{a})$; fMet-Leu-Phe $\pm \mathrm{CB}$ plus histamine ( $)$. Data shown represent the means of assay triplicates of an experiment carried out with neutrophils of one donor. Assay variation was less than $5 \%$. Similar results were obtained in three experiments carried out with neutrophils of different donors

The effect of histamine $(1 \mathrm{mM})$ on $\mathrm{O}_{2}^{-}$formation in neutrophils was studied in the presence of various concentrations of fMet-Leu-Phe and in the absence or presence of CB (Fig. 2). In the absence of CB (panel B), fMet-Leu-Phe activated $\mathrm{O}_{2}^{-}$formation with an $\mathrm{EC}_{50}$ value of $45 \mathrm{nM}$ and a maximum at $300 \mathrm{nM}$. In the absence of $\mathrm{CB}$, histamine completely prevented activation of $\mathrm{O}_{2}^{-}$formation induced by fMet-Leu-Phe at concentrations of up to $50 \mathrm{nM}$. The inhibitory effect of histamine on $\mathrm{O}_{2}^{-}$formation induced by

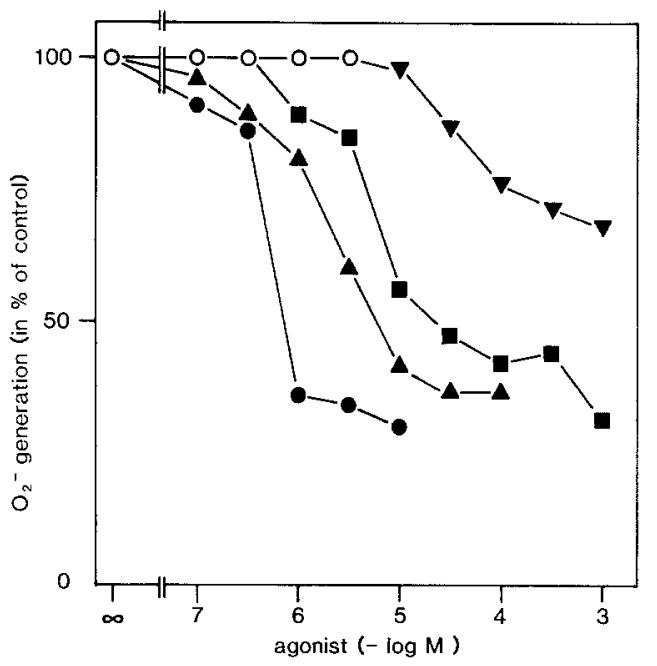

Fig. 3. Concentration-response curves to $\mathrm{PGE}_{1}$ and histaminergic agonists on $\mathrm{fMet}-\mathrm{Leu}-\mathrm{Phe}$-induced $\mathrm{O}_{2}^{-}$formation in human neutrophils. The effects of $\mathrm{PGE}_{1}$ and histaminergic agonists were studied in the presence of fMet-Leu-Phe $(1 \mu \mathrm{M})$ and $\mathrm{CB}(1 \mu / \mathrm{ml}) . \mathrm{PGE}_{1}$ and histaminergic agonists or solvent (control) were added to reaction mixtures 5 min prior to fMet-Leu-Phe. PGE $_{1}(\bullet)$; histamine (四); impromidine $(\boldsymbol{\Delta})$; betahistine $(\boldsymbol{\nabla})$. In the absence of $\mathrm{PGE}_{1}$ and histaminergic agonists, fMet-Leu-Phe induced the formation of 30.8 \pm 2.8 mmoles of $\mathrm{O}_{2}^{-} / 10^{6}$ cells. Data shown are the mean of three experiments carried out with neutrophils of different donors which varied by less than $15 \%$

fMet-Leu-Phe at a maximally stimulatory concentration $(1 \mu \mathrm{M})$ in the absence of $\mathrm{CB}$ amounted to $87 \%$. CB potentiates $\mathrm{O}_{2}^{-}$formation by increasing the number of formyl peptide receptors on the plasma membrane (Jesaitis et al. 1986). In the presence of CB (panel A), fMet-Leu-Phe activated $\mathrm{O}_{2}^{-}$formation with an $\mathrm{EC}_{50}$ value of $25 \mathrm{nM}$, reaching a maximum at a concentration of $100 \mathrm{nM}$. Histamine inhibited $\mathrm{O}_{2}^{-}$formation without altering the $\mathrm{EC}_{50}$ value and the maximally effective concentration for fMet-Leu-Pheinduced $\mathrm{O}_{2}^{-}$formation. However, histamine completely inhibited $\mathrm{O}_{2}^{-}$formation induced by a very low concentration of fMet-Leu-Phe $(10 \mathrm{nM})$ in the presence of CB. In the presence of $\mathrm{CB}$, histamine inhibited $\mathrm{O}_{2}^{-}$formation induced by fMet-Leu-Phe at a maximally stimulatory concentration by $73 \%$.

The concentration-response functions to $\mathrm{PGE}_{1}$ and various histaminergic agonists on fMet-Leu-Phe-induced $\mathrm{O}_{2}^{-}$ formation in neutrophils were compared (Fig.3). $\mathrm{PGE}_{1}$ inhibited fMet-Leu-Phe-induced $\mathrm{O}_{2}^{-}$formation by more than $70 \%$. The effect of $\mathrm{PGE}_{1}$ was half-maximal at $0.5 \mu \mathrm{M}$ and reached a plateau at a concentration of $3 \mu \mathrm{M}$. Histamine inhibited $\mathrm{O}_{2}^{-}$formation with an $\mathrm{IC}_{50}$ value of $8 \mu \mathrm{M}$ and was maximally effective at $1 \mathrm{mM}$. Impromidine, a potent $\mathrm{H}_{2}$ agonist (Durant et al. 1978), inhibited $\mathrm{O}_{2}^{-}$formation with an $\mathrm{IC}_{50}$ value of $2 \mu \mathrm{M}$. The effect of impromidine was maximal at a concentration of $30 \mu \mathrm{M}$. Impromidine and histamine were similarly effective as $\mathrm{PGE}_{1}$. Betahistine is a full agonist at $\mathrm{H}_{1}$-receptors and a weak partial agonist at $\mathrm{H}_{2}$ receptors in various peripheral tissues (Ganellin 1982). In the brain, betahistine is a partial $\mathrm{H}_{1}$ - and $\mathrm{H}_{2}$-agonist (Arrang et al. 1985). This histaminergic agonist was much less potent and effective than histamine and impromidine to inhibit $\mathrm{O}_{2}^{-}$formation. 

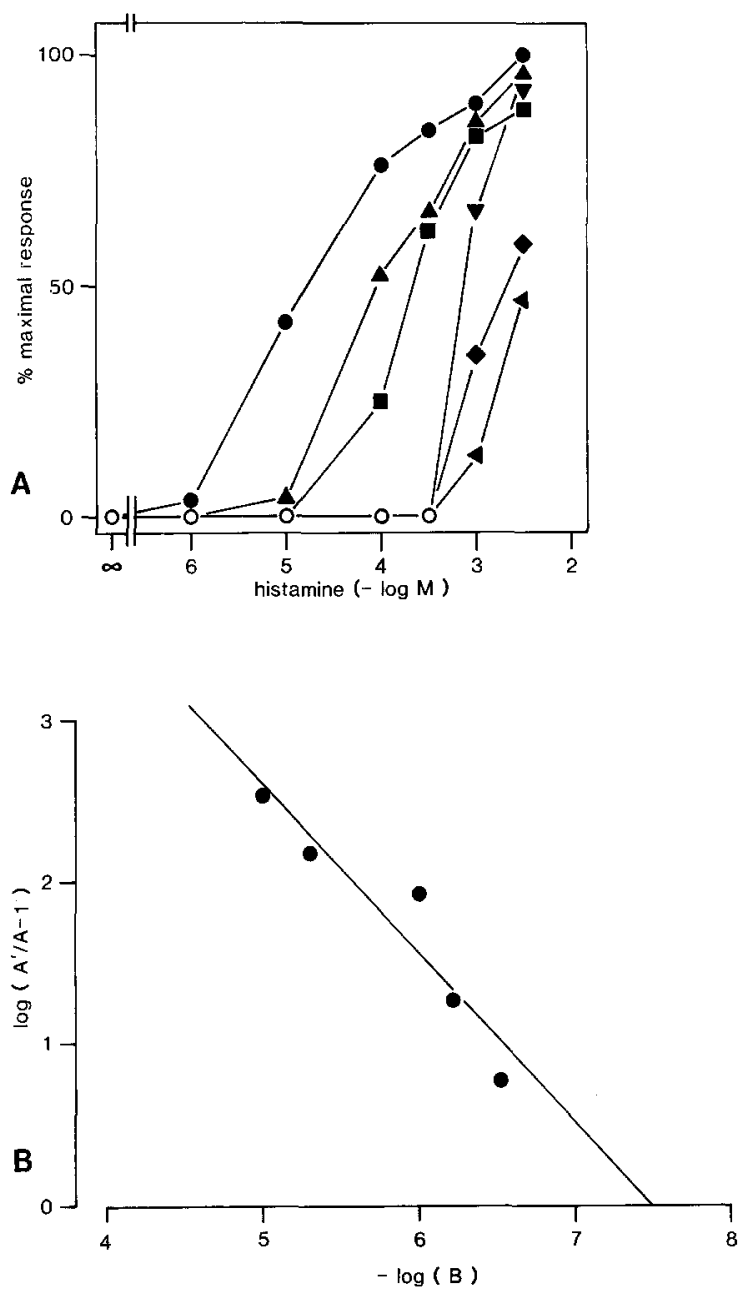

Fig. 4A, B. Effect of the $\mathrm{H}_{2}$-antagonist, famotidine, on inhibition of fMet-Leu-Phe-induced $\mathrm{O}_{2}^{-}$formation caused by histamine in human neutrophils. Panel A: The effect of famotidine at fixed concentrations on inhibition of $\mathrm{O}_{2}^{-}$formation caused by histamine was studied. CB $(1 \mu \mathrm{g} / \mathrm{ml})$ plus histamine and famotidine or solvent (control) were simultaneously added to reaction mixtures. After a preincubation period of $5 \mathrm{~min}, \mathrm{O}_{2}^{-}$formation was initiated by the addition of fMet-Leu-Phe $(1 \mu \mathrm{M})$. The concentrations of famotidine were as follows: $0 \mu \mathrm{M}(\mathbf{\bullet}) ; 0.3 \mu \mathrm{M}(\boldsymbol{\Delta}) ; 0.6 \mu \mathrm{M}(\boldsymbol{\square}) ; 1 \mu \mathrm{M}(\boldsymbol{\nabla})$; $5 \mu \mathrm{M}(\bullet) ; 10 \mu \mathrm{M}(4)$. Data shown are the means of assay triplicates of an experiment performed with neutrophils of one donor; these varied by less than $5 \%$. Similar results were obtained in two experiments carried out with neutrophils of different donors. Panel B: Schild plot analysis of the data from Panel A. The agonist dose ratios $\mathrm{A} / \mathrm{A}^{\prime}$ were calculated, $\mathrm{A}$ being the concentration of histamine producing a given effect in the absence of famotidine and $\mathrm{A}^{\prime}$ being the concentration of histamine producing a given effect in the presence of famotidine at a concentration $\mathrm{B}$. The regression line was calculated and the $\mathrm{pA}_{2}$ value (intercept of the graph with the $a b$ scissa) was calculated

With respect to the postulated stimulatory effects of $\mathrm{H}_{1}$ agonists on phagocyte functions we addressed the question whether betahistine may stimulate neutrophils. Betahistine at a concentration of $10 \mu \mathrm{M}$ did not enhance $\mathrm{O}_{2}^{-}$formation induced by fMet-Leu-Phe at concentrations of $50 \mathrm{nM}$ and $1 \mu \mathrm{M}$. As betahistine is a partial $\mathrm{H}_{2}$-agonist, this component may blunt its stimulatory effect on $\mathrm{H}_{1}$-receptors. Therefore, $\mathrm{H}_{2}$-receptors were blocked with the $\mathrm{H}_{2}$-antagonists, cimetidine or famotidine (Schunack 1987), at a concen-

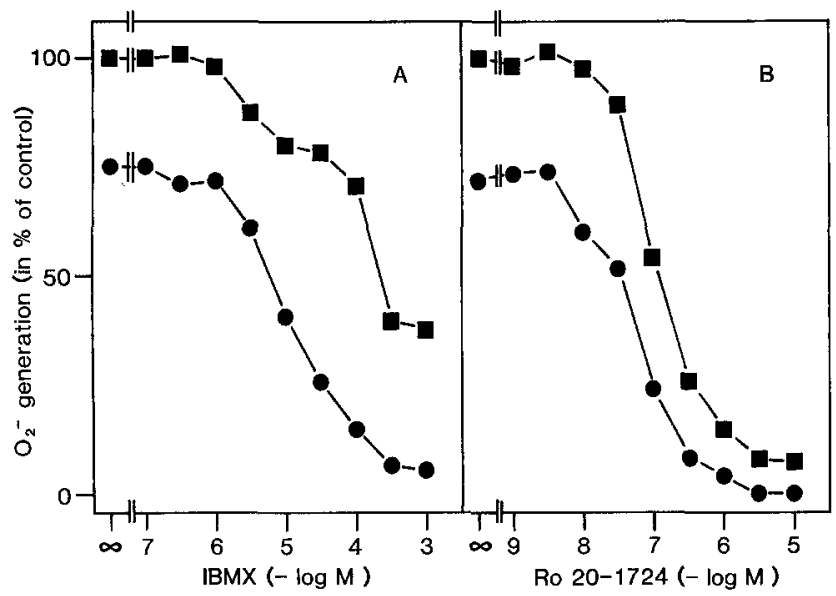

Fig. 5 A, B. Interaction of histamine and inhibitors of phosphodiesterases on fMet-Leu-Phe-induced $\mathrm{O}_{2}^{-}$generation in human neutrophils. The effects of Ro 20-1724 and IBMX were studied in the absence or presence of a submaximally inhibitory concentration of histamine $(10 \mu \mathrm{M})$. Ro 20-1724, IBMX or solvent (control) were added to reaction mixtures 5 min prior to fMet-Leu-Phe $(1 \mu \mathrm{M})$ in the absence or presence of histamine. Panel A: IBMX (ם); IBMX plus histamine (O). Panel B: Ro 20-1724 (ם); Ro 20-1724 plus histamine (-). In the absence of Ro 20-1724, IBMX and histamine, fMet-Leu-Phe plus CB $(1 \mu \mathrm{g} / \mathrm{ml})$ induced the formation of $28.8 \pm$ 2.1 nmoles of $\mathrm{O}_{2}^{-} / 10^{6}$ cells. Data shown are the mean of three experiments performed with neutrophils of different donors which varied by less than $15 \%$

tration of $10 \mu \mathrm{M}$. Alternatively, $\mathrm{H}_{2}$-receptors were stimulated with impromidine at a concentration of $10 \mu \mathrm{M}$. However, even under these conditions betahistine did not potentiate fMet-Leu-Phe-induced $\mathrm{O}_{2}^{-}$formation. In addition, betahistine itself at concentrations of $1 \mu \mathrm{M}-1 \mathrm{mM}$ did not activate $\mathrm{O}_{2}^{-}$formation in the presence or absence of CB (data not shown). Thus, we did not obtain any positive evidence for a stimulatory role of putative $\mathrm{H}_{1}$-receptors on $\mathrm{O}_{2}^{-}$formation in human neutrophils.

The apparent affinity of famotidine for neutrophil $\mathrm{H}_{2}$ receptors was assessed by Schild plot analysis (Fig. 4) (Schild 1947). Famotidine at concentrations ranging from $0.3-$ $10 \mu \mathrm{M}$ lead to parallel shifts of the concentration-response curves for histamine to the right. The transformation of these data into the Schild plot presentation was performed according to Tallarida and Jacob (1987). The equation for the regression line is $y=-1.03 x+7.70$ and the intercept with the abscissa (i.e. the $\mathrm{pA}_{2}$ value) is 7.5. These data indicate that famotidine is a competitive antagonist at neutrophil $\mathrm{H}_{2}$-receptors. In addition, the $\mathrm{pA}_{2}$ value of famotidine in neutrophils is similar to the one of famotidine in other systems (Schunack 1987). In contrast to famotidine, the $\mathrm{H}_{1}$-antagonist, diphenhydramine (Ganellin 1978; Nauta and Rekker 1978), did not reverse the inhibitory effect of histamine or betahistine on $\mathrm{O}_{2}^{-}$formation (data not shown).

The interactions of inhibitors of PDEs with histamine on $\mathrm{O}_{2}^{-}$formation in human neutrophils were studied (Fig. 5). IBMX per se inhibited fMet-Leu-Phe-induced $\mathrm{O}_{2}^{-}$formation by up to $60 \%$, the effect of the methylxanthine being halfmaximal at a concentration of $160 \mu \mathrm{M}$. The concentrationresponse curve for IBMX was, however, not sigmoid. This abnormality may be due to the fact that IBMX is also an antagonist at neutrophil adenosine $\mathrm{A}_{2}$-receptors (Schmeichel and Thomas 1987). Blockade of $\mathrm{A}_{2}$-receptors by meth- 
Table 1. Inhibition by forskolin, dbcAMP, $\mathrm{PGE}_{1}$, histamine and Ro 20-1724 and combinations of these agents of fMet-Leu-Pheinduced $\mathrm{O}_{2}^{-}$formation in human neutrophils

\begin{tabular}{|c|c|}
\hline Addition & $\begin{array}{l}\mathrm{O}_{2}^{-} \text {formation } \\
\text { (in } \% \text { of } \\
\text { control) }\end{array}$ \\
\hline Forskolin $(30 \mu \mathrm{M})$ & 77 \\
\hline $\operatorname{dbcAMP}(1 \mathrm{mM})$ & 35 \\
\hline Histamine $(1 \mathrm{mM})$ & 27 \\
\hline $\mathrm{PGE}_{1}(10 \mu \mathrm{M})$ & 20 \\
\hline Ro $20-1724(1 \mu \mathrm{M})$ & 31 \\
\hline Histamine $(1 \mathrm{mM})+$ Ro $20-1724(1 \mu \mathrm{M})$ & 10 \\
\hline $\operatorname{PGE}_{1}(10 \mu \mathrm{M})+\operatorname{Ro}_{20-1724}(1 \mu \mathrm{M})$ & 6 \\
\hline Histamine $(1 \mathrm{mM})+\mathrm{PGE}_{1}(10 \mu \mathrm{M})$ & $17^{\mathrm{a}}$ \\
\hline \multicolumn{2}{|l|}{ Histamine $(1 \mathrm{mM})+\mathrm{PGE}_{1}(10 \mu \mathrm{M})$} \\
\hline$+\operatorname{Ro} 20-1724(1 \mu \mathrm{M})$ & $6^{\mathrm{b}}$ \\
\hline
\end{tabular}

$\mathrm{O}_{2}^{-}$formation induced by fMet-Leu-Phe at a concentration of $1 \mu \mathrm{M}$ was measured in the absence (control) or presence of various agents or combinations of agents. Experiments were carried out in the presence of CB $(1 \mu \mathrm{g} / \mathrm{ml})$. In the presence of CB and in the absence of inhibitors fMet-Leu-Phe induced the formation of $24.5 \pm 2.9$ nmoles of $\mathrm{O}_{2}^{-} / 10^{6}$ cells. Agents or solvent were added to reaction mixtures 5 min prior to fMet-Leu-Phe. Data shown are the mean of four experiments carried out with neutrophils of different donors; these varied by less than $15 \%$ : Statistical significance of the effects of combinations of histamine plus PGE 1 was assessed using the Wilcoxon test. " Comparison of $\mathrm{PGE}_{1}$ versus $\mathrm{PGE}_{1}$ plus histamine, not significant; ${ }^{b}$ comparison of $\mathrm{PGE}_{1}$ plus Ro 20-1724 versus $\mathrm{PGE}_{1}$ plus Ro 20-1724 plus histamine, not significant

ylxanthines causes potentiation of $\mathrm{O}_{2}^{-}$formation (Schmeichel and Thomas 1987). Thus, both inhibitory and stimulatory components may contribute to the net effect of IBMX on $\mathrm{O}_{2}^{-}$formation. In contrast to IBMX, the specific inhibitor of cyclic AMP-specific PDE, Ro 20-1724, inhibited $\mathrm{O}_{2}^{-}$formation with a sigmoid concentration response function, its effect being half-maximal at $0.13 \mu \mathrm{M}$. IBMX plus histamine or Ro 20-1724 plus histamine additively inhibited $\mathrm{O}_{2}^{-}$formation. In addition, histamine shifted the midpoints of the inhibition curves for the PDE inhibitors to the left.

The data obtained so far suggest that histamine inhibitis $\mathrm{O}_{2}^{-}$formation through an increase in cyclic AMP. Therefore, the effects of forskolin which directly activates adenylyl cyclase (Barovsky and Brooker 1985) and of the cell-permeable analogue of cyclic AMP, dbcAMP, on $\mathrm{O}_{2}^{-}$formation were studied (Table 1). Forskolin at a concentration of $30 \mu \mathrm{M}$ and dbcAMP at a concentration of $1 \mathrm{mM}$ inhibited fMet-Leu-Phe-induced $\mathrm{O}_{2}^{-}$formation by $23 \%$ and $65 \%$, respectively. Table 1 also shows that the combination of histamine plus $\mathrm{PGE}_{1}$ at maximally effective concentrations did not accomplish complete inhibition of $\mathrm{O}_{2}^{-}$formation, regardless of whether Ro 20-1724 was present or not. These data indicate that $\mathrm{PGE}_{1}$ alone maximally activates adenylyl cyclase and that histamine, acting through a different receptor, cannot significantly increase the activity of adenylyl cyclase.

The effects of histamine, $\mathrm{PGE}_{1}$ and Ro 20-1724 on $\mathrm{O}_{2}^{-}$ formation induced by fMet-Leu-Phe, fMet-Leu-Phe plus PAF or fMet-Leu-Phe plus ATP were compared. PAF $(1 \mu \mathrm{M})$ and ATP $(100 \mu \mathrm{M})$ enhanced fMet-Leu-Phe-induced $\mathrm{O}_{2}^{-}$formation in the absence of CB by more than two-fold (Table 2). Histamine, $\mathrm{PGE}_{1}$ and Ro 20-1724 at maximally effective concentrations inhibited $\mathrm{O}_{2}^{-}$formation induced by
Table 2. Inhibition by $\mathrm{PGE}_{1}$, histamine and Ro 20-1724 of $\mathrm{O}_{2}^{-}$ formation induced by fMet-Leu-Phe, fMet-Leu-Phe plus PAF or fMet-Leu-Phe plus ATP in human neutrophils

\begin{tabular}{lrcc} 
Stimulus & \multicolumn{3}{c}{$\begin{array}{c}\text { fMet-Leu-Phe } \begin{array}{c}\text { fMet-Leu-Phe } \\
+ \text { PAF }\end{array} \\
\text { fMet-Leu-Phe } \\
+ \text { ATP }\end{array}$} \\
\hline Addition & $\mathrm{O}_{2}^{-}$generation (in \% of control) \\
\hline Histamine $(1 \mathrm{mM})$ & 23 & $42^{\mathrm{a}}$ & $31^{\mathrm{b}}$ \\
PGE $_{1}(10 \mu \mathrm{M})$ & 6 & $27^{\mathrm{a}}$ & $10^{\mathrm{b}}$ \\
Ro 20-1724 $(1 \mu \mathrm{M})$ & 19 & $38^{\mathrm{a}}$ & $22^{\mathrm{b}}$ \\
\hline
\end{tabular}

Histamine, PGE 1 , Ro 20-1724 or solvent (control) were added to reaction mixtures $5 \mathrm{~min}$ prior to stimuli. Experiments were carried out in the absence of $\mathrm{CB}$. The concentrations of stimuli were as follows: fMet-Leu-Phe, $1 \mu \mathrm{M}$; PAF, $1 \mu \mathrm{M}$; ATP, $100 \mu \mathrm{M}$. In the absence of PAF or ATP, fMet-Leu-Phe induced the formation of $2.2 \pm 0.4$ nmoles of $\mathrm{O}_{2}^{-} / 10^{6}$ cells. fMet-Leu-Phe plus PAF induced the formation of $7.1 \pm 1.2$ nmoles of $\mathrm{O}_{2}^{-} / 10^{6}$ cells and fMet-LeuPhe plus ATP induced the formation of $4.3 \pm 0.3$ nmoles of $\mathrm{O}_{2}^{-}$ $10^{6}$ cells. The percentages shown in the Table are referred to these control values. Data shown are the mean of six experiments carried out with neutrophils of different donors; these varied by less than $15 \%$. The statistical significance of the differential sensitivity to inhibition of $\mathrm{O}_{2}^{-}$formation by cyclic AMP-increasing agents was assessed using the Wilcoxon test. ${ }^{a}$ Comparison of fMet-Leu-Phe versus fMet-Leu-Phe plus PAF, $p<0.05 ;{ }^{\mathrm{b}}$ comparison of fMetLeu-Phe versus fMet-Leu-Phe plus ATP, not significant

fMet-Leu-Phe or fMet-Leu-Phe plus ATP to similar extents. These agents also inhibited $\mathrm{O}_{2}^{-}$formation induced by fMetLeu-Phe plus PAF, but this activation was significantly less sensitive to an inhibition by cyclic AMP-increasing agents than the former types of activation. Stimulus-dependent inhibition of $\mathrm{O}_{2}^{-}$formation by cyclic AMP-increasing agents has also been noted in two recent studies (Gryglewski et al. 1987; Seifert et al. 1989a).

The effects of histamine, $\mathrm{PGE}_{1}$, Ro 20-1724, dbcAMP and forskolin and combinations of some of these agents on fMet-Leu-Phe-induced exocytosis of $\beta$-glucuronidase and aggregation were studied. These experiments were performed in order to answer the question whether histamine causes general inhibition of neutrophil activation. At a maximally stimulatory concentration, fMet-Leu-Phe induced the release of $40 \%$ of the cellular content of $\beta$-glucuronidase (Table 3). Forskolin did not inhibit fMet-Leu-Phe-induced exocytosis. $\mathrm{PGE}_{1}$, histamine, Ro 20-1724 and dbcAMP inhibited fMet-Leu-Phe-induced release of $\beta$-glucuronidase by $23 \%, 12 \%, 17 \%$ and $11 \%$, respectively. PGE $_{1}$ or histamine plus Ro 20-1724 additively inhibited the release of $\beta$ glucuronidase. Similarly to $\mathrm{O}_{2}^{-}$formation, histamine did not significantly enhance inhibition of exocytosis caused by $\mathrm{PGE}_{1}$ at a maximally stimulatory concentration both in the absence and presence of Ro 20-1724.

As was the case for $\beta$-glucuronidase release, forskolin did not inhibit $\mathrm{fMet}-\mathrm{Leu}$-Phe-induced aggregation. $\mathrm{PGE}_{1}$, histamine and dbcAMP inhibited aggregation induced by fMet-Leu-Phe by $39 \%, 14 \%$ and $10 \%$, respectively (Table 4). Ro 20-1724 at a subtreshold inhibitory concentration $(10 \mathrm{nM})$ synergistically enhanced the inhibitory effects of $\mathrm{PGE}_{1}$ and histamine.

Finally, we studied the functional role of histamine in the regulation of $\mathrm{O}_{2}^{-}$formation in differentiated HL-60 cells (Table 5). Upon exposure to fMet-Leu-Phe, dbcAMP-differentiated HL-60 cells generated higher amounts of $\mathrm{O}_{2}^{-}$than 
Table 3. Effect of forskolin, dbcAMP, $\mathrm{PGE}_{1}$, histamine and Ro 201724 and combinations of these agents of fMet-Leu-Phe-induced release of $\beta$-glucuronidase in human neutrophils

$\begin{array}{ll}\text { Addition } & \beta \text {-glucuronidase } \\ & \text { release (in } \% \text { of } \\ & \text { control) }\end{array}$

\begin{tabular}{|c|c|}
\hline Forskolin $(30 \mu \mathrm{M})$ & 98 \\
\hline $\operatorname{dbcAMP}(1 \mathrm{mM})$ & 89 \\
\hline Histamine $(1 \mathrm{mM})$ & 88 \\
\hline $\mathrm{PGE}_{1}(10 \mu \mathrm{M})$ & 77 \\
\hline Ro $20-1724(1 \mu \mathrm{M})$ & 83 \\
\hline Histamine $(1 \mathrm{mM})+$ Ro $20-1724(1 \mu \mathrm{M})$ & \\
\hline $\mathrm{PGE}_{1}(10 \mu \mathrm{M})+\operatorname{Ro} 20-1724(1 \mu \mathrm{M})$ & \\
\hline Histamine $(1 \mathrm{mM})+\mathrm{PGE}_{1}(10 \mu \mathrm{M})$ & \\
\hline Histamine $(1 \mathrm{mM})+\mathrm{PGE}_{1}(10 \mu \mathrm{M})$ & \\
\hline$+\operatorname{Ro} 20-1724(1 \mu \mathrm{M})$ & \\
\hline
\end{tabular}

The release of $\beta$-glucuronidase induced by fMet-Leu-Phe at a concentration of $1 \mu \mathrm{M}$ during an incubation time of $10 \mathrm{~min}$ was measured in the absence (control) or presence of various agents or combinations of agents. In the absence of stimulatory and inhibitory agents, the release of $\beta$-glucuronidase and lactate dehydrogenase amounted to $5 \%$ of cellular content, none of the agents studied having an effect on the release of lactate dehydrogenase (data not shown). Forskolin, dbcAMP, Histamine, PGE $_{1}$ and Ro 20-1724 were added to reaction mixtures 5 min prior to fMet-Leu-Phe. Data shown are the mean four experiments carried out with neutrophils of different donors; these varied by less than $15 \%$. In the absence of inhibitors, fMet-Leu-Phe induced the release of $40 \pm 4 \%$ of the cellular content of $\beta$-glucuronidase. Statistical significance of the effects of combinations of histamine plus $\mathrm{PGE}_{1}$ was assessed using the Wilcoxon test. a Comparison of $\mathrm{PGE}_{1}$ versus $\mathrm{PGE}_{1}$ plus histamine, not significant; ${ }^{b}$ comparison of $\mathrm{PGE}_{1}$ plus Ro $20-1724$ versus $\mathrm{PGE}_{1}$ plus Ro 20-1724 plus histamine, not significant

the $\mathrm{Me}_{2} \mathrm{SO}$-differentiated ones, possibly due to the expression of higher numbers of formyl peptide receptors in the former cells (Chaplinski and Niedel 1982). The effectiveness of histaminergic agonists at a concentration of $100 \mu \mathrm{M}$ to inhibit $\mathrm{O}_{2}^{-}$formation in differentiated HL-60 cells was compared. Histamine and impromidine were similarly effective inhibitors of $\mathrm{O}_{2}^{-}$formation both in dbcAMP- and $\mathrm{Me}_{2} \mathrm{SO}$-differentiated cells. In contrast, betahistine showed no substantial inhibitory effect. In comparison to histamine, $\mathrm{PGE}_{1}$ was a more effective inhibitor of $\mathrm{O}_{2}^{-}$formation in either cell type. In $\mathrm{Me}_{2} \mathrm{SO}$-differentiated cells the effects of histaminergic agonists and $\mathrm{PGE}_{1}$ were less prominent than in the dbcAMP-differentiated ones. Thus, the induction of myeloid differentiation of HL-60 cells with dbcAMP does not impair the subsequent inhibition of $\mathrm{O}_{2}^{-}$formation by hormonal activators of adenylyl cyclase. These data indicate that the inhibition of $\mathrm{O}_{2}^{-}$formation by cyclic AMP-increasing agents is independently regulated of cyclic AMP-induced differentiation.

\section{Discussion}

We show here that histamine inhibits $\mathrm{O}_{2}^{-}$formation, exocytosis and aggregation in human neutrophils and reduces $\mathrm{O}_{2}^{-}$formation in differentiated HL-60 cells. Histaminergic agonists inhibit $\mathrm{O}_{2}^{-}$formation in the potency order impromidine $>$ histamine $\gg$ betahistine. In addition, the effects of histamine are competitively antagonized by the $\mathrm{H}_{2}$ -
Table 4. Effect of forskolin, dbcAMP, $\mathrm{PGE}_{1}$, histamine and Ro 201724 on fMet-Leu-Phe-induced aggregation of human neutrophils

\begin{tabular}{ll}
\hline Addition & $\begin{array}{l}\text { Aggregation } \\
\text { (in \% of control) }\end{array}$ \\
\hline Forskolin $(30 \mu \mathrm{M})$ & 100 \\
dbcAMP $(1 \mathrm{mM})$ & 90 \\
Histamine $(1 \mathrm{mM})$ & 86 \\
PGE $(10 \mu \mathrm{M})$ & 61 \\
Ro $20-1724(10 \mathrm{nM})$ & 99 \\
Histamine $(1 \mathrm{mM})+$ Ro $20-1724(10 \mathrm{nM})$ & 71 \\
PGE $_{1}(10 \mu \mathrm{M})+$ Ro $20-1724(10 \mathrm{nM})$ & 42 \\
\hline
\end{tabular}

To stirred suspensions of neutrophils various agents or solvent (control) were added $3 \mathrm{~min}$ prior to the addition of fMet-Leu-Phe $(1 \mu \mathrm{M})$. The extent of aggregation is referred to that induced by fMet-Leu-Phe $(1 \mu \mathrm{M})$. Data shown represent the mean of three experiments carried out with neutrophils of different donors; these varied by less than $15 \%$

Table 5. Inhibition by histamine, impromidine, betahistine and $\mathrm{PGE}_{1}$ of $\mathrm{fMet-Leu-Phe-induced} \mathrm{superoxide} \mathrm{formation} \mathrm{in} \mathrm{differen-}$ tiated HL-60 cells

\begin{tabular}{llc}
\hline Differentiation-inducing agent & dbcAMP & $\mathrm{Me}_{2} \mathrm{SO}$ \\
\hline Addition & $\begin{array}{l}\mathrm{O}_{2}^{-} \text {generation } \\
\text { (in \% of control) }\end{array}$ & \\
\hline Histamine $(100 \mu \mathrm{M})$ & 50 & 70 \\
Impromidine $(100 \mu \mathrm{M})$ & 58 & 80 \\
Betahistine $(100 \mu \mathrm{M})$ & 95 & 102 \\
PGE $_{1}(10 \mu \mathrm{M})$ & 29 & 46
\end{tabular}

To induce differentiation, HL-60 cells were cultured for $48 \mathrm{~h}$ with $0.2 \mathrm{mM}$ dibutyryl cyclic AMP (dbcAMP) or for $120 \mathrm{~h}$ with $160 \mathrm{mM}$ dimethyl sulfoxide $\left(\mathrm{Me}_{2} \mathrm{SO}\right)$. Thereafter, cells were harvested and were suspended in the buffer for determination of $\mathrm{O}_{2}^{-}$formation not supplemented with the differentiation-inducing agents. $\mathrm{CB}$ $(1 \mu \mathrm{g} / \mathrm{ml})$ plus histamine, impromidine, betahistine, $\mathrm{PGE}_{1}$ or solvent (control) were added to reaction mixtures $5 \mathrm{~min}$ prior to fMet-LeuPhe $(1 \mu \mathrm{M})$. In dbcAMP- and $\mathrm{Me}_{2} \mathrm{SO}$-differentiated HL-60 cells, fMet-Leu-Phe induced the formation of $19.2 \pm 4.6$ and $12.1 \pm$ 2.6 nmoles of $\mathrm{O}_{2}^{-} / 10^{6}$ cells, respectively. The percentages shown in the Table are referred to these control values. Data shown represent the mean of four experiments carried out with different preparations of HL- 60 cells; these varied by less than $10 \%$

antagonist, famotidine, but not by the $\mathrm{H}_{1}$-antagonist, diphenhydramine. In agreement with our present results concerning histaminergic inhibition of $\mathrm{O}_{2}^{-}$formation, Gespach and Abita (1982) and Gespach et al. (1982) reported on a similar potency order of histaminergic agonists to stimulate the accumulation of cyclic AMP in human neutrophils and in HL-60 cells. Histamine and $\mathrm{PGE}_{1}$ are similarly effective inhibitors of the activation of myeloid cell functions. The effects of histamine and $\mathrm{PGE}_{1}$ on the accumulation of cyclic AMP (Gespach and Abita 1982; Gespach et al. 1982; Lad et al. 1985) and on inhibition of neutrophil function are additively enhanced by inhibitors of PDEs, such as IBMX and Ro 20-1724, suggesting that both intercellular signal molecules act by a mechanism they have in common. We conclude that histamine inhibits various myeloid functions via $\mathrm{H}_{2}$-receptors through activation of adenylyl cyclase and increased formation of cyclic AMP. 
fMet-Leu-Phe induces a transient activation of $\mathrm{O}_{2}^{-}$formation which is rapid in onset. As $\mathrm{PGE}_{1}$ and histamine rapidly inhibit $\mathrm{O}_{2}^{-}$formation, the functional response to these agents apparently does not require sustained accumulation of cyclic AMP. Lad et al. (1985) have shown that small increments in the intracellular concentration of cyclic AMP induced by $\mathrm{PGE}_{1}$ are sufficient to inhibit $\mathrm{O}_{2}^{-}$formation. Thus, activation of $\mathrm{O}_{2}^{-}$formation by fMet-Leu-Phe is an inhibitable process which is rapidly terminated by addition of competitive antagonists, e.g. Boc-PLPLP, or by addition of hormonal activators of adenylyl cyclase, e.g. histamine and $\mathrm{PGE}_{1}$.

Histamine does not alter the $\mathrm{EC}_{50}$ value and the maximally stimulatory concentration of fMet-Leu-Phe-induced $\mathrm{O}_{2}^{-}$formation in neutrophils in the presence of $\mathrm{CB}$, suggesting that histamine does not mediate its effects via modification of the number and/or affinity state of formyl peptide receptors. The differential sensitivity of various classes of stimulatory agonists to an inhibition by histamine suggests that these stimulatory signal molecules activate different signal transduction pathways which are differently modulated by an increase of cyclic AMP. In addition, activation of $\mathrm{O}_{2}^{-}$formation is more sensitive to inhibition by histamine and $\mathrm{PGE}_{1}$ than aggregation and exocytosis. Furthermore, forskolin and dbcAMP mimick the differential inhibition profiles induced by histamine and $\mathrm{PGE}_{1}$. Thus, it is not likely that this differential sensitivity is due to the parallel activation of stimulatory $\mathrm{H}_{1}$-receptors and inhibitory $\mathrm{H}_{2}$-receptors. A greater sensitivity of $\mathrm{O}_{2}^{-}$formation than of exocytosis to inhibition by prostaglandins has recently been noted by Lad et al. (1985). All these data also suggest that differential sensitivity of G-proteins to a cyclic AMP-mediated inhibition of their function is not involved in this phenomenon as dbcAMP and forskolin act at sites distal from G-proteins. Possibly, protein kinase A-catalyzed phosphorylation reactions differently affect the functional state of proteins involved in the regulation of various effector systems, finally leading to activation of $\mathrm{O}_{2}^{-}$formation, exocytosis and aggregation.

There is recent evidence that platelet products modulate $\mathrm{O}_{2}^{-}$formation in human neutrophils. Platelets synergistically enhance and inhibit $\mathrm{O}_{2}^{-}$formation via the release of ATP and prostaglandins, respectively (Ward et al. 1988; Metha et al. 1988). In addition, PAF which is secreted from neutrophils, basophils and mast cells potentiates fMet-LeuPhe-induced $\mathrm{O}_{2}^{-}$formation (Siraganian 1983; Dewald and Baggiolini 1985; Seifert et al. 1989c). We show here that histamine, $\mathrm{PGE}_{1}$ and Ro 20-1724 inhibit $\mathrm{O}_{2}^{-}$formation induced by fMet-Leu-Phe, fMet-Leu-Phe plus PAF or fMetLeu-Phe plus ATP. Basophils and mast cells release high quantities of histamine upon stimulation with various intercellular signal molecules such as IgE, complement C5a and fMet-Leu-Phe (Siraganian 1983; Warner et al. 1987). These findings suggest that basophils via the release of histamine may play an inhibitory role in the formyl-peptide-, PAFand ATP-induced activation of $\mathrm{O}_{2}^{-}$formation. These results support the concept that various types of blood cells communicate via the release of intercellular signal molecules to regulate cytotoxic functions of neutrophils. In addition, histamine may play a negative feed-back role in the regulation of cytotoxic functions of basophils and mast cells themselves, as these cells generate $\mathrm{O}_{2}^{-}$as well (Henderson and Kaliner 1978; Kitagawa et al. 1980).
Acknowledgements. The authors are grateful to Mrs. Evelyn Glaß for expert technical assistance, to the laboratory staff of the Institute for donating blood and to Mrs. Rosemarie Krüger for help in the preparation of the manuscript. This work was supported by grants of the Deutsche Forschungsgemeinschaft and the Fonds der Chemischen Industrie.

\section{References}

Absolom DR (1986) Basic methods for the study of phagocytosis Methods Enzymol 132:95-180

Arrang J-M, Garbarg M, Schwartz J-C (1983) Auto-inhibition of brain histamine release mediated by a novel class $\left(\mathrm{H}_{3}\right)$ of histamine receptor. Nature 302:832-837

Arrang J-M, Garbarg M, Quach TT, Tuong MDT, Yerimian E, Schwartz J-C (1985) Actions of betahistine at histamine receptors in the brain. Eur J Pharmacol 111:73-84

Arrang J-M, Garbarg M, Lancelot J-C, Lecomte J-M, Pollard H, Robba M, Schunack W, Schwartz J-C (1987) Highly potent and selective ligands for histamine $\mathrm{H}_{3}$-receptors. Nature 327: $117-$ 123

Ash ASF, Schild HO (1966) Receptors mediating some actions of histamine. Br J Pharmacol Chemother 27:427-439

Barovsky K, Brooker G (1985) Forskolin potentiation of cholera toxin-stimulated cyclic AMP accumulation in intact $\mathrm{C6}-2 \mathrm{~B}$ cells. Evidence for enhanced $\mathrm{G}_{\mathrm{s}}-\mathrm{C}$ coupling. Mol Pharmacol 28:502-507

Black JW, Duncan WAM, Durant CJ, Ganellin CR, Parsons EM (1972) Definition and antagonism of histamine $\mathrm{H}_{2}$-receptors. Nature 236:385-390

Buschauer A, Schunack, W, Arrang J-M, Garbarg M, Schwartz JC, Young JM (1989) Histamine receptors. In: Williams M, Glennon RA, Timmermans PBMWM (eds) Clinical Pharmacology Vol 13: Receptor Pharmacology and Function. New York, Basel, pp 293-348

Chaplinski TJ, Niedel JE (1982) Cyclic nucleotide-induced maturation of human promyelocytic leukemia cells. J Clin Invest $70: 953-964$

Dewald B, Baggiolini M (1985) Activation of NADPH oxidase in human neutrophils. Synergism between MLP and the neutrophil products PAF and $\mathrm{LTB}_{4}$. Biochem Biophys Res Commun 128:297-304

Diaz P, Jones DG, Kay AB (1979) Histamine-coated particles generate superoxide $\left(\mathrm{O}_{2}^{-}\right)$and chemiluminescence in alveolar macrophages. Nature 278:454-456

Dubyak GR, Cowen DS, Meuller LM (1988) Activation of inositol phospholipid breakdown in HL-60 cells by $P_{2}$-purinergic receptors for extracellular ATP. Evidence for mediation by both pertussis toxin-sensitive and pertussis toxin-insensitive mechanisms. J Biol Chem 263:18108-18117

Durant GJ, Duncan WAM, Ganellin CR, Parsons ME, Blakemore $\mathrm{RC}$, Rasmussen $A C$ (1978) Impromidine (SK \& F 92676) is a very potent and specific agonist for histamine $\mathrm{H}_{2}$ receptors. Nature 276:403-405

Durant GJ, Ganellin CR, Hills DW, Miles PD, Parsons ME, Pepper ES, White GR (1985) The histamine $\mathrm{H}_{2}$ receptor agonist impromidine: Synthesis and structure-activity considerations. J Med Chem 28:1414-1422

Ganellin CR (1978) Chemistry and structure-activity relationships of $\mathrm{H}_{2}$-receptor antagonists. In : Rocha e Silva M (ed) Handbook of experimental pharmacology, vol XVIII/2. Histamine II and anti-histaminics. Chemistry, metabolism and physiological and pharmacological actions. Springer, Berlin Heidelberg New York, pp 251-294

Ganellin CR (1982) Chemistry and structure-activity relationship of drugs acting at histamine receptors. In: Ganellin CR, Parsons (eds) Pharmacology of histamine receptors. Wright, Bristol, pp $10-102$ 
Gespach C, Abita J-P (1982) Human polymorphonuclear neutrophils. Pharmacological characterization of histamine receptors mediating the elevation of cyclic AMP. Mol Pharmacol $21: 78-$ 85

Gespach C, Saal F, Cost H, Abita J-P (1982) Identification and characterization of surface receptors for histamine in the human promyelocytic leukemia cell line HL-60. Comparison with human peripheral neutrophils. Mol Pharmacol 22:547-553

Gryglewski RJ, Szczeklik A, Wandzilak M (1987) The effect of six prostaglandins, prostacyclin and iloprost on generation of superoxide anions by human polymorphonuclear leukocytes stimulated by zymosan or formyl-methionyl-leucyl-phenylalanine. Biochem Pharmacol 24:4209-4213

Henderson WR, Kaliner M (1978) Immunologic and nonimmunologic generation of superoxide from mast cells and basophils. $J$ Clin Invest 61:187-196

Jesaitis AJ, Tolley JO, Allen RA (1986) Receptor-cytoskeleton interaction and membrane traffic may regulate chemoattractantinduced superoxide production in human granulocytes. J Biol Chem 261:13662-13669

Kitagawa S, Takaku F, Sakamoto S (1980) Serine protease inhibitors inhibit superoxide production by human basophils stimulated by anti-IgE. Biochem Biophys Res Commun 95:801-806

Korchak HM, Wilkenfeld C, Rich AM, Radin AR, Vienne K, Rutherford LE (1984) Stimulus response coupling in the human neutrophil. Differential requirements for receptor occupancy in neutrophil responses to a chemoattractant. $J$ Biol Chem 259:7439-7445

Kuhns DB, Wright DG, Nath J, Kaplan SS, Basford RE (1988) ATP induces transient elevations of $\left[\mathrm{Ca}^{2+}\right]_{\mathrm{i}}$ in human neutrophils and primes these cells for enhanced $\mathrm{O}_{2}^{-}$generation. Lab Invest 58:448-453

Lad PM, Goldberg BJ, Smiley PA, Olson CV (1985) Receptorspecific threshold effects of cyclic AMP are involved in the regulation of enzyme release and superoxide production from human neutrophils. Biochim Biophys Acta 846:286-295

Malech HL, Gallin MD (1987) Neutrophils in human disease. New Engl J Med 317:687-694

Markert M, Andrews PC, Babior BM (1984) Measurement of $\mathrm{O}_{2}^{-}$ production by human neutrophils. The preparation and assay of NADPH oxidase-containing particles from human neutrophils. Methods Enzymol 105:358-365

Metha JL, Lawson D, Metha P (1988) Modulation of human neutrophil superoxide production by selective thromboxane synthetase inhibitor U63,557A. Life Sci 43:923-928

Nauta WT, Rekker RF (1978) Structure-activity relationships of $\mathrm{H}_{1}$-receptor antagonists. In: Rocha e Silva M (ed) Handbook of experimental pharmacology. Vol. XVIII/2. Histamine II and anti-histaminics. Chemistry, metabolism and physiological and pharmacological actions. Springer, Berlin Heidelberg New York, pp 215-249

Owen DAA (1987) Inflammation - histamine and 5-hydroxytryptamine. Br Med Bull 43:256-269

Plaut M, Lichtenstein M (1982) Histamine and immune response. In: Ganellin CR, Parsons ME (eds) Pharmacology of histamine receptors. Wright, Bristol, pp 392-435

Puustinen T, Uotila P (1984) Thromboxane formation in human polymorphonuclear leukocytes is inhibited by prednisolone and stimulated by leukotrienes $\mathrm{B}_{4}, \mathrm{C}_{4}, \mathrm{D}_{4}$ and histamine. Prostaglandins Leukotrienes Med 14:161-167

Rossi $\mathrm{F}$ (1986) The $\mathrm{O}_{2}^{-}$-forming NADPH oxidase of phagocytes: nature, mechanisms of activation and function. Biochim Biophys Acta 853:65-89
Sandborg RR, Smolen JE (1988) Biology of disease. Early biochemical events in leukocyte activation. Lab Invest 59:300-320

Schild HO (1947) pA, a new scale for the measurement of drug antagonism. Br J Pharmacol 2:189-206

Schmeichel CJ, Thomas LL (1987) Methylxanthine bronchodilators potentiate multiple human neutrophil functions. J Immunol 138:1896-1903

Schunack W (1987) What are the differences between the $\mathrm{H}_{2}$-receptor antagonists. Aliment Pharmacol Ther 1:493S-503S

Schwartz J-C, Arrang J-M, Garbarg M (1986) Three classes of histamine receptors in brain. Trends Pharmacol Sci 7:24-28

Seifert R, Schächtele C (1988) Studies with protein kinase C inhibitors presently available cannot elucidate the role of protein kinase $\mathrm{C}$ in the activation of NADPH oxidase. Biochem Biophys Res Commun 152:585-592

Seifert R, Schultz G (1987) Reversible activation of NADPH oxidase in membranes of HL-60 leukemic cells. Biochem Biophys Res Commun 146:1296-1302

Seifert R, Rosenthal W, Schultz G (1986) Guanine nucleotides stimulate NADPH oxidase in membranes of human neutrophils. FEBS Lett 205:161-165

Seifert R, Burde R, Schultz G (1989a) Activation of NADPH oxidase by purine and pyrimidine nucleotides involves $\mathrm{G}$ proteins and is potentiated by chemotactic peptides. Biochem $\mathrm{J}$ $259: 813-819$

Seifert R, Burde R, Schultz G (1989b) Lack of effect of opioid peptides, morphine and naloxone on superoxide formation in human neutrophils and HL-60 leukemic cells. Naunyn-Schmiedeberg's Arch Pharmacol 340:101 - 106

Seifert R, Wenzel K, Eckstein F, Schultz G (1989c) Purine and pyrimidine nucleotides potentiate activation of NADPH oxidase and degranulation by chemotactic peptides and induce aggregation of human neutrophils via $\mathrm{G}$ proteins. Eur J Biochem 181:277-285

Seligmann BE, Fletcher MP, Gallin JI (1983) Histamine modulation of human neutrophil oxidative metabolism, locomotion, degranulation, and membrane potential changes. J Immunol $130: 1902-1909$

Siraganian RP (1983) Histamine secretion from mast cells and basophils. Trends Pharmacol Sci 4:432-437

Stolc V (1977) Mechanism of regulation of adenylate cyclase activity in human polymorphonuclear leukocytes by calcium, guanosyl nucleotides, and positive effectors. J Biol Chem 252:19011907

Tallarida RJ, Jacob LS (1987) $\mathrm{pA}_{2}$ analysis I: Schild plot. In: Tallarida RJ, Jacob LS (eds) Manual of pharmacologic calculations with computer programs. 2nd edn Springer, Berlin Heidelberg New York, pp 53-56

Warner JA, Yancey KB, McGlashan DW (1987) The effect of pertussis toxin on mediator release from human basophils. $J$ Immunol 139:161 - 165

Ward PA, Cunningham TW, McCulloch KK, Phan SH, Powell J, Johnson KJ (1988) Platelet enhancement of $\mathrm{O}_{2}^{-}$responses in stimulated human neutrophils. Identification of platelet factor as adenine nucleotide. Lab Invest 58:37-47

Weishaar RE (1987) Multiple molecular forms of phosphodiesterase: An overview. J Cyclic Nucleotide Protein Phosphor Res $11: 463-472$

Received March 10, 1989/Accepted August 5, 1989 